\title{
WISP1 wt Allele
}

National Cancer Institute

\section{Source}

National Cancer Institute. WISP1 wt Allele. NCI Thesaurus. Code C52020.

Human WISP1 wild-type allele is located within $8 q 24.1-q 24.3$ and is approximately $38 \mathrm{~kb}$ in length. This allele, which encodes WNT1-inducible-signaling pathway protein 1, is involved in the mediation of diverse developmental processes. 